Andrzej Graczyk*

\title{
ROZWÓJ ZRÓWNOWAŻONY W GOSPODARCE RYNKOWEJ
}

\section{Wprowadzenie}

Pojawienie się i rozwój koncepcji rozwoju zrównoważonego było reakcją na zagrożenia rozwoju, które występowały zarówno w rozwiniętych gospodarkach rynkowych, jak i w gospodarkach krajów rozwijających się. Rozwój zrównoważony wydaje się być bezpieczny i trwały. Ma to zapewnić podejście, w którym aspekty społeczne i ekologiczne są traktowane na równi z ekonomicznymi.

Idea rozwoju zrównoważonego koncentruje się na celach i sposobach pomiaru ich osiągania. Natomiast kluczowe wydaje się zastosowanie mechanizmów, które pozwolą na zastosowanie odpowiednich działań i środków.

System gospodarki rynkowej ukształtował się głównie pod wpływem i na potrzeby rozwoju gospodarczego. W odniesieniu do aspektów społecznych i ekologicznych rozwoju rynek nie spełniał roli regulatora działań podmiotów, a jeśli nawet, to w kierunkach nieodpowiadających idei rozwoju zrównoważonego.

Rozwój zrównoważony będzie się odbywać w warunkach gospodarki rynkowej. Dlatego kluczową kwestią wydaje się znalezienie takich rozwiązań, by wszystkie aspekty rozwoju zrównoważonego mogły zostać w spójny sposób włączone do sposobu działania gospodarki rynkowej. Celem artykułu jest ocena możliwości oraz sposobów urzeczywistniania idei rozwoju zrównoważonego w warunkach gospodarki rynkowej.

* Wydział Nauk Ekonomicznych, Uniwersytet Ekonomiczny we Wrocławiu. 


\section{Słabości funkcjonowania rynku we współczesnej gospodarce}

Rynek odgrywa szczególną rolę we współczesnej gospodarce. Określenie „gospodarka rynkowa" stanowi najbardziej syntetyczną charakterystykę sposobu i celów działania podmiotów. Na rynku dokonują one wyborów, które umożliwiają im osiąganie celów gospodarczych, a w konsekwencji zaspokojenie potrzeb.

W ujęciu ekonomii neoklasycznej mechanizm rynkowy to proces automatycznego, niezależnego od woli poszczególnych podmiotów regulowania procesów produkcji i podziału dóbr. Mechanizm rynkowy wprowadza ład w systemie, którego podstawą jest dążenie poszczególnych podmiotów do maksymalizacji indywidualnych celów. Regulacja rynkowa ma szereg cech określających dostosowanie podmiotów. System informacji rynkowej jest oparty na relacjach cen i innych instrumentach ekonomicznych. Rola sygnałów z otoczenia jest decydująca dla wyboru celów podmiotów. Ustalają one cele samodzielnie. Podstawowym kryterium racjonalności jest maksymalizacja nadwyżki ekonomicznej przychodów nad kosztami działalności. Zasilanie zewnętrzne podmiotów w pieniądz/kapitał w długim okresie nie decyduje o osiąganiu celów. Istotne znaczenie ma natomiast efektywność.

Ograniczenia zasobowe mogą stanowić barierę rozwoju gospodarki rynkowej. W szczególności ograniczoność zasobów pracy i zasobów środowiska mogą być trudne lub niemożliwe do pokonania, nawet przy obfitości kapitału pieniężnego. Mogą one też wpływać na rozwój kapitału rzeczowego w kierunku zastępowania brakujących zasobów ludzkich czy środowiskowych. Dodatkowym ograniczeniem mogą być zanieczyszczenia środowiska, które powodują koszty zewnętrzne ${ }^{1}$. Informacja cenowa o istnieniu i sile takich ograniczeń nie jest tworzona samoistnie w postaci cen tych zasobów, wygenerowanych przez mechanizm rynkowy.

W ekonomii neoklasycznej zauważa się, że w praktyce gospodarka rynkowa charakteryzuje się występowaniem wielu niedoskonałości (błędów) rynku, w następstwie których mechanizm rynkowy nie prowadzi do osiągnięcia efektywności alokacyjnej, ogólnej równowagi rynkowej, maksymalizacji nadwyżki ekonomicznej, a w konsekwencji dobrobytu społecznego. Do podstawowych niedoskonałości rynku zalicza się m.in.:

- występowanie dóbr publicznych, wśród których szczególne miejsce mają niektóre zasoby przyrodnicze,

\footnotetext{
1 Więcej na ten temat w: A. Graczyk, Ekologiczne koszty zewnętrzne. Identyfikacja, szacowanie, internalizacja, Wydawnictwo Ekonomia i Środowisko, Białystok 2005.
} 
- niedoskonałości wynikające $\mathrm{z}$ dostępu i przepływu informacji oraz występowanie niepewności i ryzyka,

- występowanie efektów zewnętrznych, które mogą mieć charakter pozytywny (korzyści zewnętrzne) lub negatywny (koszty zewnętrzne) $)^{2}$.

W ekonomii instytucjonalnej propozycje zdefiniowania pojęcia rynku odwołują się do instytucji wymiany. Wymiana jest wydarzeniem, aktem jednorazowym lub procesem, jeżeli powtarza się i spełnia pewne warunki wstępne. Rynek to całokształt instytucji zapewniających strukturę relacji wymiany przy pomocy systemu ograniczeń ${ }^{3}$ Stabilny porządek rynkowy może powstać tylko w społeczeństwie, w którym istnieje już macierz (struktura) nieformalnych norm społecznych i moralnych, a więc i ograniczenia dotyczące zachowania jednostek, kształtujące stopień wzajemnego zaufania i akceptację pewnych wartości. Dopiero na wyższym szczeblu ewolucji instytucja władzy (państwo) wprowadzi normy formalne, ułatwiające wymianę właśnie pod warunkiem, że nie będą one wyraźnie sprzeczne z normami tradycyjnymi, nieformalnymi ${ }^{4}$.W ujęciu ekonomii instytucjonalnej rynki nie są doskonałe. Zawodność rynków dotyczy takich zjawisk, jak: dobra publiczne, asymetria informacji, efekty zewnętrzne, defekty koordynacji i kooperacji, funkcjonowanie firm w obszarach rosnących produkcji, występowanie kosztów transakcyjnych, problemów agencji ${ }^{5}$.

Istnienie niedoskonałości w procesach alokacji potencjalnie mogłoby skłaniać uczestników rynku do tworzenia instytucji przetargowych w procesach dostępu do dóbr. Gdyby takie rozwiązanie było możliwe, to można by oczekiwać wykształcenia się reguł postępowania podmiotów, które w konsekwencji pozwalałyby na utworzenie rynku. W rzeczywistości jednak tak się nie dzieje. Nieodzowne staje się wówczas wyznaczenie ram i ograniczeń procesów wymiany.

\section{Wdrażanie rozwoju zrównoważonego w gospodarce rynkowej}

Stworzenie idei zrównoważonego rozwoju stanowiło reakcję na dostrzegalne w teorii i praktyce słabości i ograniczenia działania gospodarki rynkowej. Ogólnym

\footnotetext{
2 B. Fiedor, Regulacja ekologiczna jako rodzaj regulacji publicznej w gospodarce rynkowej - ujęcie normatywne a ekonomia polityczna regulacji, [w:] Konflikty i wspótpraca w realizacji strategii ekorozwoju, Biblioteka „Ekonomia i Środowisko” nr 30, Wrocław 2003.

3 W. Stankiewicz, Ekonomika instytucjonalna, Zarys wykładu, wyd. III uzup., Wydawnictwo Prywatnej Wyższej Szkoły Businesu, Administracji i Technik Komputerowych,Warszawa 2012, s. 82-83.

4 Ibidem.

5 Z. Staniek, Ekonomia instytucjonalna. Dlaczego instytucje sa ważne, Difin, Warszawa 2017, s. 266E-267.
} 
celem koncepcji zrównoważoności jest wyważony rozwój gospodarczy, społeczny i środowiskowy ${ }^{6}$. Cele rozwoju zrównoważonego zostały sformułowane w dokumencie końcowym szczytu ONZ z 25-27 września 2015 r. ${ }^{7}$ Jednakże wśród siedemnastu celów tego programu nie znalazły się odniesienia do rynku. Postulat zrównoważoności gospodarki rynkowej byłby wszak uzasadniony rosnącym znaczeniem globalizowania się gospodarki oraz rosnącym znaczeniem zawodności rynków globalnych dla powstawania kryzysów ${ }^{8}$. Powodem braku „docenienia” zrównoważoności gospodarki rynkowej na poziomie globalnym jest zapewne to, że co do istoty rozwój zrównoważony oznacza rozwój endogeniczny, czyli stymulowany przez czynniki wewnętrzne ${ }^{9}$. „Środowiskiem” zrównoważonego rozwoju staje się więc rynek krajowy. Jego model i mechanizmy mogą być kształtowane w zależności od celów i etapów rozwoju ${ }^{10}$. Nie musi to oznaczać, że zrównoważony rozwój w sposób naturalny zostanie wpisany w realia gospodarki rynkowej. Wydaje się, że szanse na to tworzy istnienie i narastanie słabości gospodarki rynkowej, w szczególności prowadzące do spowolnienia lub wstrzymania rozwoju. Natomiast wysoka dynamika rozwoju może być powodem uznawania, że rynek będzie skuteczną ochroną przed ewentualnymi zagrożeniami i nierównościami procesów rozwoju. Sprawność rynku jest więc ważnym czynnikiem wyznaczającym moment zainicjowania procesu wdrażania elementów rozwoju zrównoważonego.

Wprowadzenie elementów rozwoju zrównoważonego odbywać się będzie w warunkach rynkowych i na warunkach, na jakich funkcjonuje rynek. Słabo rozwinięty rynek daje możliwości szybkiego wprowadzania rozwoju zrównoważonego w tych obszarach, w których mechanizmy rynkowe nie działają lub nie są sprawne. Pojawia się przy tym wątpliwość dotycząca wpływu takiej decyzji na dynamikę rozwoju. Mechanizmy rynkowe wydają się zapewniać efektywność, natomiast nie da się jej na takim samym poziomie zagwarantować dla rozwoju, w których by się od nich odchodziło. Aby tak się nie stało, konieczne jest przygotowanie warunków do wdrażania rozwoju zrównoważonego. Powinny one pozwolić także na przekształcanie

6 Europejski Komitet Ekonomiczno-Społeczny Centrum Monitorowania Rozwoju Zrównoważonego, Program prac CMRZ na lata 2015-2018, Bruksela, 2 grudnia 2016 r.

7 United Nations, Transforming our world: the 2030 Agenda for Sustainable Development, Resolution adopted by the General Assembly on 25 September 2015, A/RES/70/1, http://www.un.org/ga/search/view_ doc.asp?symbol=A/RES/70/1\&Lang=E

8 A. Peszko, Wpływ Oliviera E. Williamsona na doskonalenie instytucji rynkowej gospodarki globalnej, [w:] Nowa ekonomia instytucjonalna wobec kryzysu gospodarczego, red. S. Rudolf, Wydawnictwo WSEP im. prof. Edwarda Lipińskiego w Kielcach, Kielce 2012.

9 Ekonomia rozwoju, red. B. Fiedor, K. Kociszewski, Wydawnictwo UE we Wrocławiu, Wrocław 2010.

10 A. Matysiak, M. Raftowicz-Filipkiewicz, Wpływ procesów endogenicznych na rozwój zrównoważony, „Studia Ekonomiczne. Zeszyty Naukowe UE w Katowicach” nr 311, 2017. 
istniejących rynków oraz uzupełnianie rynków brakujących. Ich kształtowanie może już wspierać rozwój zrównoważony.

Rozwinięty system gospodarki rynkowej może być czynnikiem sprzyjającym transformacji w kierunku rozwoju zrównoważonego. Będzie to wymagało wprowadzenia elementów rozwoju zrównoważonego do funkcjonujących mechanizmów rynkowych oraz stworzenia rynkowych mechanizmów działania „nierynkowych” aspektów rozwoju zrównoważonego (społecznego, ekologicznego). Taki scenariusz zależy od determinacji władz publicznych oraz od przygotowania podmiotów do tych zmian.

Przekształcenia gospodarki rynkowej w kierunku rozwoju zrównoważonego mogą mieć różne podstawy. Ich identyfikacja i dobór odpowiednich działań będą zależne od teoretycznego spojrzenia na charakter gospodarki rynkowej. Ocena rozwoju gospodarki z punktu widzenia ekonomii neoklasycznej będzie wskazywać na potrzebę doskonalenia działania rynków i urynkowienia tych obszarów, które są niezbędne dla funkcjonowania rozwoju zrównoważonego. W szczególności będzie tu chodziło o społeczne i ekologiczne aspekty rozwoju.

Rozwój zrównoważony wymaga świadomego określania jego kierunków i mechanizmów. Powinno to sprawić, że podejmowane przez podmioty na różnych szczeblach decyzje będą zbieżne z ideą rozwoju zrównoważonego. Dla ekonomii neoklasycznej podstawą rozwoju we współczesnej gospodarce są decyzje podejmowane w celu maksymalizacji korzyści przez podmioty działające w warunkach rynkowych. Ekonomia instytucjonalna $\mathrm{z}$ kolei wskazuje na konieczność zbudowania systemu norm i wartości, które są właściwe idei rozwoju zrównoważonego. Dopiero ich upowszechnienie umożliwia stworzenie formalnych instytucji wbudowanych w system rynkowy.

Wydaje się, że transformacja gospodarki rynkowej w kierunku rozwoju zrównoważonego będzie wymagać zarówno działań właściwych z punktu widzenia ekonomii neoklasycznej, jak i takich, które zaleca ujęcie instytucjonalne. Konieczne jest więc tworzenie mechanizmów i instrumentów rozwoju zrównoważonego bazujące na przyjętym przez podmioty systemie norm ${ }^{11}$.

W rezultacie nie zachodzi dylemat wyboru, w którym należy poświęcić dobre strony gospodarki rynkowej w imię urzeczywistniania idei rozwoju zrównoważonego albo pozostawać w modelu gospodarki rynkowej mającej coraz większe problemy równoważenia rozwoju. Rozwój zrównoważony powinien uzyskać rynkowy wymiar w tym sensie, że jest zgodny z ideą i mechanizmami gospodarki rynkowej.

11 Interesujące jest też sięgnięcie do koncepcji społecznej gospodarki rynkowej.Więcej na ten temat zob. M. Łuszczyk, Konkretyzacja kategorii gospodarczej rozwoju trwałego, „Acta Universitatis Lodziensis, Folia Oeconomica" nr 2(313), 2015. 


\section{Rynkowe kształtowanie rozwoju zrównoważonego na przykładzie wykorzystania i ochrony środowiska}

Rozwiązania rynkowe, które wpływają na wdrażanie rozwoju zrównoważonego, mogą być stosowane w wąskim i w szerokim zakresie. W pierwszym przypadku służą przede wszystkim ograniczaniu negatywnych oddziaływań na środowisko. Są domeną polityki ekologicznej. W szerokim zakresie powinny sprzyjać utrzymaniu i poprawie jakości środowiska oraz efektywnemu i korzystnemu ze względów społecznych wykorzystaniu zasobów. Są wtedy inicjowane i wdrażane w ramach polityki rozwoju.

Ograniczenie uciążliwych zanieczyszczeń i innych negatywnych oddziaływań na środowisko wymaga regulacji, które powodują, że działania podmiotów zostają właściwie ukierunkowane. Konieczne jest inicjowanie rozwiązań, których wykonawców trzeba dopiero znaleźć. Typowe instrumenty administracyjno-prawne i ekonomiczne będą mało przydatne. Muszą one być stosowane w warunkach cechujących się znaczną pewnością sposobu irezultatu działań, jakie chce się uzyskać w wyniku stosowania instrumentów. Natomiast cechą rozwiązań rynkowych jest to, że w sposób naturalny są adresowane do anonimowego odbiorcy. Zachęcają do wykorzystania okazji, co sprawia, że pojawiają się wykonawcy i działania, których wcześniej nie było.

Tworzenie rozwiązań rynkowych polityki ekologicznej, przydatnych w warunkach obiektywnych ograniczeń, dotyczyć może w szczególności:

- wykorzystania zielonych zamówień publicznych dla wspierania popytu na produkty przyjazne środowiskowo i przeciwdziałania rozwojowi rynków towarów „nieprzyjaznych” ekologicznie,

- wsparcia publicznego działalności inwestycyjnej i eksploatacyjnej podmiotów ze środków będących w dyspozycji polityki ekologicznej,

- tworzenia mechanizmu rynkowego podziału nieuniknionych uciążliwości ekologicznych,

- rozszerzania rynku pozwoleń emisyjnych na gospodarstwa domowe,

- rynkowego sposobu podziału zobowiązań w zakresie kosztów zewnętrznych ${ }^{12}$.

Przyjęcie szerokiego zakresu rozwiązań rynkowych dla wdrażania zrównoważonego rozwoju dotyczy w szczególności czterech obszarów:

- alokacji zasobów środowiskowych,

- utrzymania lub poprawy jakości środowiska,

12 Więcej na ten temat w: A. Graczyk, A.M. Graczyk, Wprowadzanie mechanizmów rynkowych do ochrony środowiska, PWE, Warszawa 2011. 
- ukierunkowania aktywności podmiotów na działania sprzyjające zrównoważonemu rozwojowi,

- odtwarzania środowiska lub wzmacniania jego funkcji13

Działania wynikające z refleksji teoretycznej ekonomii instytucjonalnej powinny koncentrować się na dwóch obszarach: instytucji praw własności oraz tworzenia instrumentów rynkowych ochrony środowiska. Działania te powinna inicjować władza publiczna, głównie w ramach polityki ekologicznej.

Konieczne jest uwzględnienie problemu praw własności, biorąc szczególnie pod uwagę to, czy prawa te zostały zdefiniowane oraz w jakim zakresie może występować dysponowanie prawami własności w odniesieniu do poszczególnych funkcji środowiska. W istocie chodzi więc o określenie, kto i w jaki sposób może wykorzystywać funkcje środowiska. Prawa własności odnoszące się do dóbr środowiskowych nie są zwykle nieograniczone. Ograniczenia w sferze dysponowania podmiotem własności w odniesieniu do prywatnych dóbr środowiskowych wynikają z nałożenia na podmiot i/lub na inne podmioty obowiązków, które nakładane są w interesie ogólnym, a które sprawiają, że uprawnienia stają się wtórne względem obowiązków ${ }^{14}$. Natomiast w odniesieniu do dóbr środowiskowych mających cechy dóbr publicznych ograniczenia praw własności są dalej idące i wynikają z podstawowych wymagań stawianych dobrom publicznym ${ }^{15}$.

W działalności człowieka środowisko występuje głównie w trzech rolach: dostarczyciela czynników produkcji, odbiornika zanieczyszczeń oraz otoczenia tworzącego warunki działania.W odniesieniu do wykorzystywania środowiska w funkcji dostarczyciela czynników wytwórczych prawa własności środowiska są zwykle zdefiniowane i przypisane do konkretnych podmiotów. Gdy takie dobro środowiskowe jest objęte prywatną własnością, to nie muszą występować ekologiczne koszty zewnętrzne. Jest to bowiem zgodne z regułą ,im bardziej prywatny charakter ma efekt zewnętrzny, tym bardziej jest prawdopodobne, że może być (będzie) regulowany przez rynek i transakcje rynkowe" ${ }^{16}$. Tym samym problem tworzenia przez państwo formalnych norm i instrumentów rynkowych służących ochronie środowiska ma stosunkowo małe znaczenie.

13 Szersze omówienie w: A. Graczyk, Instrumenty rynkowe w zrównoważonym rozwoju (na przykładzie polityki ekologicznej), [w:] Sektor finansowy. Stymulatory i zagrożenia rozwoju, red. K. Pietraszkiewicz, Polskie Towarzystwo Ekonomiczne, Warszawa 2015, s. 122-135.

14 J. Boć, K. Nowacki, E. Samborska-Boć, Ochrona środowiska, Kolonia Limited, Wrocław 2003/2004, s. $345-346$.

15 Zob. Property rights and environmental problems, red. B.A. Larson, Aldershot, Burlington, Ashgate 2003.

16 K.-G. Loefgren, Rynek a efekty zewnętrzne, [w:] Ekonomia środowiska i zasobów naturalnych, red. H. Folmer, L. Gabel, H. Opshoor, T. Żylicz, Wydawnictwo Krupski i S-ka, Warszawa 1996. 
Środowisko ma też specyficzną wartość usługową w postaci zdolności przyjęcia i zneutralizowania emitowanego zanieczyszczenia. Zwykle jest ona wykorzystywana wspólnie przez wiele podmiotów. W przypadku nadmiernego jej wykorzystania powstają uciążliwości i zagrożenia, które prowadzą do powstania kosztów zewnętrznych. Podmioty niekiedy mogą same tworzyć zasady i normy regulujące sposób korzystania z tej funkcji środowiska, np. ograniczenie lub zakaz grilowania w ogródkach domowych przyjmowane przez wspólnoty mieszkańców, ograniczenia wjazdu samochodami do centrów miast przyjmowane przez samorządy, procedury postępowania $z$ niebezpiecznymi odpadami przyjmowane przez grupy producentów itp. Z czasem te nieformalne instytucje ulegają formalizacji, np. w postaci zorganizowania miejsc do grilowania, udostępnianych nieodpłatnie lub odpłatnie, wprowadzenia opłat za wjazd samochodami do centrów miast, zorganizowania lub wyznaczenia wyspecjalizowanych firm utylizujących odpłatnie odpady. Dzięki temu następuje alokacja praw własności do wykorzystywania środowiska w tej funkcji. Podmioty uzyskują uprawnienia do korzystania $\mathrm{z}$ dobra środowiskowego w ilości, która wynika $\mathrm{z}$ ich własnych decyzji o nabyciu odpowiedniej liczby uprawnień, z uwzględnieniem ograniczeń określanych przez władze publiczne. Alokacja uprawnień, a w konsekwencji dostępu do korzystania z dobra środowiskowego, może też wykorzystywać mechanizm rynkowy, który nadaje uprawnieniom ceny wskazujące na rzadkość dóbr środowiskowych.

Środowisko tworzy też warunki działalności podmiotów. Ma najczęściej cechy „dobra wspólnego". Prawa własności w odniesieniu do usług środowiska nie są w ogóle lub są niedostatecznie zdefiniowane. Nie można wyłączyć podmiotu z użytkowania dobra wspólnego. W efekcie pojawia się nadmierne użytkowanie środowiska i jego degradacja. Przykładem jest wykorzystywanie wód powierzchniowych jako odbiornika ścieków.

Nadmiernie zanieczyszczone środowisko (w szczególności powietrze czy woda) to dobra negatywne (antydobra), z których użytkowania podmioty zwykle nie mogą się wyłączyć. Korzystanie z zanieczyszczonego środowiska łączy się najczęściej z wyższymi kosztami w porównaniu z korzyściami związanymi z użytkowaniem dobra. Przykładem jest narażenie na zanieczyszczenia w ramach tzw. niskiej emisji lub narażenie na nadmierny hałas.

Zachowania podmiotów wynikają $\mathrm{w}$ istocie $\mathrm{z}$ nie $\mathrm{w}$ pełni zdefiniowanych praw własności do środowiska, albo wskutek tego, że prawa te są najczęściej przypisane anonimowemu społeczeństwu.W ramach mechanizmu rynkowego nie ustalą się samoistnie ceny ich usług świadczonych przez te elementy środowiska w procesie produkcji i konsumpcji. Podmioty nie będąc indywidualnymi właścicielami praw do korzystania ze środowiska lub do jego zanieczyszczania, nie mogą przystąpić do procesów wymiany. 
Zwykle rozwiązanie problemu nadmiernego zanieczyszczania lub nadmiernego korzystania ze środowiska następuje na drodze tworzenia nakazów, zakazów, pozwoleń na działalność itp. Powstają w ten sposób sformalizowane instytucje regulacji administracyjnej. Mogą one jednak zostać przekształcone w formy regulacji rynkowej korzystania z zasobów i funkcji środowiska. Wymaga to ustalenia indywidualnych pozwoleń zbywalnych, które mogą być rozdysponowane $\mathrm{w}$ formie przetargu i/lub handlu pozwoleniami. Zapewnia to nieprzekraczanie zakładanych poziomów korzystania ze środowiska, niezależnie od tego, kto jest korzystającym. Pozwala także na ukierunkowanie działań podmiotów zgodne z zasadami rozwoju zrównoważonego. Jest zgodne z logiką działania instytucji rynkowych i powinno zapewnić większą efektywność, a tym samym wzrost dobrobytu społecznego przy zachowaniu wymaganej ze względów ekologicznych i społecznych jakości środowiska. Ceny za prawa do korzystania ze środowiska będą się kształtować na zasadach znajdowania równowagi rynkowej, a nie na zasadzie decyzji władz publicznych ${ }^{17}$.

\section{Uwagi końcowe}

Rynek jest środowiskiem i sposobem regulacji działań podmiotów we współczesnej gospodarce. Jego funkcjonowanie nie jest wolne od błędów. Rynek nie obejmuje wszystkich obszarów gospodarowania. Mimo tych słabości zarówno obecne, jak i przyszłe gospodarowanie oraz funkcjonowanie społeczeństwa odbywać się będą w warunkach rynkowych.

Rozwój zrównoważony jest $\mathrm{z}$ definicji rozwojem społeczno-gospodarczym. Idea rozwoju zrównoważonego była odpowiedzią na problemy powstające w gospodarce rynkowej. Jednak wyznaczanie celów w zakresie rozwoju zrównoważonego nie zapewnia stworzenia modelu gospodarki, który będzie alternatywą gospodarki rynkowej.

Przekształcanie gospodarki oznaczać raczej będzie włączenie i doskonalenie mechanizmów rynkowych do gospodarki ukierunkowanej na rozwój zrównoważony. Transformacja systemu gospodarowania z modelu promującego rozwój maksymalizujący dochód pieniężny (zysk przedsiębiorcy, dochód pieniężny gospodarstwa domowego) do modelu rozwoju zrównoważonego będzie mieć podstawy wynikające z działań tych podmiotów. Ich ukierunkowanie będzie się jednak różnić w zależności od teoretycznego ujęcia istoty regulacyjnej roli rynku.

17 Więcej na ten temat w: A. Graczyk, Instrumenty rynkowe polityki ekologicznej. Teoria i praktyka, Wydawnictwo UE we Wrocławiu, Wrocław 2013, s. 110. 
Z punktu widzenia ekonomii neoklasycznej podstawowym kierunkiem działań powinno być stworzenie warunków do rynkowego wdrażania celów rozwoju zrównoważonego. Ekonomia instytucjonalna z kolei wskazuje na konieczność zbudowania systemu norm i wartości, które właściwe są idei rozwoju zrównoważonego. Dopiero ich upowszechnienie tworzy warunki do powstania formalnych instytucji wbudowanych w system rynkowy.

Trzy sfery rozwoju zrównoważonego - gospodarka, społeczeństwo i środowisko - nie powinny jednak funkcjonować według odrębnych reguł. O skutecznym urzeczywistnianiu rozwoju zrównoważonego będą decydować takie rozwiązania, które upowszechnią w obszarze „środowisko" rynkowe parametry (rynki, ceny, zasady dokonywania transakcji) i warunki podejmowania decyzji przez podmioty. Wprowadzenie takich parametrów skłoni je do dokonywania rachunku efektywności ekonomicznej.

Rozwiązania rynkowe zastosowane do regulacji jakości środowiska, a także sposobu i zakresu korzystania z jego usług i zasobów są zgodne z logiką gospodarki rynkowej. Są zrozumiałe i akceptowalne dla podmiotów, które przecież zasadniczą część decyzji podejmują na podstawie sygnałów rynkowych. Przynoszą poprawę efektywności gospodarowania, zarówno w skali społecznej, jak i indywidualnej. Wydaje się więc uzasadnione dążenie do rozszerzania form i zakresu rynkowej regulacji jakości środowiska przyrodniczego.

\section{Literatura}

Boć J., Nowacki K., Samborska-Boć E., Ochrona środowiska, Kolonia Limited, Wrocław 2003/2004.

Ekonomia rozwoju, red. B. Fiedor, K. Kociszewski, Wydawnictwo UE we Wrocławiu, Wroclaw 2010.

Europejski Komitet Ekonomiczno-Społeczny Centrum Monitorowania Rozwoju Zrównoważonego, Program prac CMRZ na lata 2015-2018, Bruksela, 2 grudnia 2016 r.

Fiedor B., Regulacja ekologiczna jako rodzaj regulacji publicznej w gospodarce rynkowej - ujecie normatywne a ekonomia polityczna regulacji, [w:] Konflikty i wspólpraca w realizacji strategii ekorozwoju, Biblioteka „Ekonomia i Środowisko” nr 30, Wrocław 2003.

Graczyk A., Ekologiczne koszty zewnętrzne. Identyfikacja, szacowanie, internalizacja, Wydawnictwo Ekonomia i Środowisko, Białystok 2005.

Graczyk A., Instrumenty rynkowe polityki ekologicznej. Teoria i praktyka, Wydawnictwo UE we Wrocławiu, Wrocław 2013. 
Graczyk A., Instrumenty rynkowe w zrównoważonym rozwoju (na przykładzie polityki ekologicznej), [w:] Sektor finansowy. Stymulatory i zagrożenia rozwoju, red. K. Pietraszkiewicz, Polskie Towarzystwo Ekonomiczne, Warszawa 2015, s. 122-135.

Graczyk A., Graczyk A.M., Wprowadzanie mechanizmów rynkowych do ochrony środowiska, PWE, Warszawa 2011.

Loefgren K.-G., Rynek a efekty zewnętrzne, [w:] Ekonomia środowiska i zasobów naturalnych, red. H. Folmer, L. Gabel, H. Opshoor, T. Żylicz, Wydawnictwo Krupski i S-ka, Warszawa 1996.

Łuszczyk M., Konkretyzacja kategorii gospodarczej rozwoju trwałego, „Acta Universitatis Lodziensis, Folia Oeconomica" nr 2(313), 2015.

Matysiak A., Raftowicz-Filipkiewicz M., Wpływ procesów endogenicznych na rozwój zrównoważony, „Studia Ekonomiczne. Zeszyty Naukowe UE w Katowicach” nr 311, 2017.

Peszko A., Wplyw Oliviera E. Williamsona na doskonalenie instytucji rynkowejgospodarki globalnej, [w:] Nowa ekonomia instytucjonalna wobec kryzysu gospodarczego, red. S. Rudolf, Wydawnictwo WSEP im. prof. Edwarda Lipińskiego w Kielcach, Kielce 2012.

Polski Komitet ds. UNESCO, Przekształcamy nasz świat: program działań na rzecz zrównoważonego rozwoju do roku 2030, http://www.unesco.pl/unesco/cele-i-zadania-zrownowazonego-rozwoju

Property rights and environmental problems, red. B. A. Larson, Aldershot, Burlington, Ashgate 2003.

Staniek Z., Ekonomia instytucjonalna. Dlaczego instytucje sa ważne, Difin, Warszawa 2017.

Stankiewicz W., Ekonomika instytucjonalna, Zarys wykładu, wyd. III uzup., Wydawnictwo Prywatnej Wyższej Szkoły Businesu, Administracji i Technik Komputerowych,Warszawa 2012.

United Nations, Transforming our world: the 2030 Agenda for Sustainable Development, Resolution adopted by the General Assembly on 25 September 2015, A/RES/70/1, http://www.un.org/ga/search/view_doc.asp?symbol=A/RES/70/1\&Lang=E

\section{Sustainable Development in a Market Economy}

The aim of the article is to assess the possibilities and ways to implement the idea of sustainable development in a market economy. Economic and social development encounters limitations due to weaknesses and market failures. The concept of sustainable development indicates mainly development goals. Their achievement, however, requires paying attention to the conditions and methods of operation of various entities. Sustainable development will take place under market economy conditions. 
From the point of view of the neoclassical economics, the basic direction of activities should be creation of conditions for market implementation of sustainable development goals. Institutional economics indicates the need to build a system of norms and values that are appropriate to the idea of sustainable development. Only their dissemination creates conditions for the creation of formal institutions which are part of the market system. However, it is advisable to combine these methods.

The implementation of sustainable development in the management of environmental resources and environmental protection requires increasing the scope of defining property rights and assigning them to specific entities. On this basis, one can create market mechanisms and expand the scope of market instruments for environmental protection. Such solutions are consistent with the logic of the market economy and will be understandable as well as acceptable to entities.

Keywords: market, sustainable development, market economy

\section{Le développement durable dans l'économie de marché}

L'objectif de cet article est d'évaluer les possibilités et les moyens de mettre en œuvre l'idée de développement durable dans les conditions d'une économie de marché. Le développement économique et social rencontre des limites dues aux faiblesses et aux défaillances du marché. Le concept de développement durable s'intéresse surtout aux objectifs de développement. Leur réalisation nécessite toutefois de prêter attention aux conditions et aux modalités de fonctionnement des entités concernées. Le développement durable se fera dans des conditions d'économie de marché.

Du point de vue de l'économie néoclassique, l'orientation fondamentale des activités devrait être de créer des conditions pour l'implémentation des objectifs de développement durable conformément aux règles du marché. L'économie institutionnelle indique la nécessité de construire un système de normes et de valeurs adaptées à l'idée de développement durable. Seule leur diffusion peut créer des conditions propices à la création d'institutions formelles intégrées dans le système de marché. Cependant, il est recommandé de combiner ces méthodes.

L'implémentation du développement durable dans la gestion des ressources environnementales et la protection de l'environnement implique la nécessité d'élargir la portée de la définition des droits de propriété et de les attribuer à des entités spécifiques. Sur cette base, il est possible de créer des mécanismes de marché et d'élargir la portée des instruments de marché pour la protection de 
l'environnement. Ces solutions sont compatibles avec la logique de l'économie de marché et seront compréhensibles et acceptables pour les entités concernées.

Mots-clés: marché, développement durable, économie de marché

\section{Устойчивое развитие в условиях рыночной экономики}

Цель статьи - оценить возможности и способы реализации идеи устойчивого развития в условиях рыночной экономики. Экономическое и социальное развитие сталкивается с ограничениями из-за недостатков и провалов рынка. Концепция устойчивого развития указывает, главным образом, на цели развития. Однако, их достижение требует внимания к условиям и методам работы субъектов. Устойчивое развитие будет проводится в условиях рыночной экономики.

С точки зрения неоклассической экономики основным направлением активности должно являться создание условий для рыночного внедрения целей устойчивого развития. Институциональная экономика указывает на необходимость построения системы норм и ценностей, которые соответствуют идее устойчивого развития. Только их распространение обеспечит условия для создания формальных учреждений, встроенных в рыночную систему. Однако, целесообразным является объединение этих методов.

Внедрение устойчивого развития в управление природными ресурсами и в охране окружающей среды требует расширения дефиниции прав собственности и назначения их конкретным субъектам. Исходя из этого, можно создать рыночные механизмы и расширить диапазон рыночных инструментов в сфере защиты окружающей среды. Такие решения согласуются с логикой рыночной экономики и будут понятны и приемлемы для субъектов.

Ключевые слова: рынок, устойчивое развитие, рыночная экономика 